the phases of mitosis have been restored), leading on to the basic organisation of the Metazoa. Then follow chapters dealing with the functions of various systems, including the integration of activities by the nervous system and endocrine glands. This comprises a consideration of such diverse subjects as enzymes, photosynthesis, oxidation, muscle action, breathing movements, transfer of respiratory gases, blood composition, clotting, kidney function, vitamins, endocrines, the placenta, and reflex arcs. Reproduction, breeding behaviour and embryonic development are accompanied by a chapter on Mendelian heredity. An account of the general principles of taxonomy is a welcome feature, and there is a summary of the main groups of animals. The chapter on ecology has been enlarged by the addition of marine habitats, and is followed by a good description of the elements of the geographical distribution of animals, of palæontology and of the modification of species. There are a glossary of nearly forty pages and - for the American teacher-a most useful list of $16-\mathrm{mm}$. motion pictures and film strips that can be used to supplement some of the material in the book. Each film is listed under the first chapter to which it is applicable, and the running time of the film is given together with the addresses of the producers or distributors.

The way of the teacher is certainly made easy by the provision of a biok of this nature, which can be thoroughly recommended for an elementary course in animal biology.

The book is well printed on good paper, and the line diagrams for the most part are clear and well chosen. It is all the more regrettable, therefore, that a certain number of very poor and badly reproduced figures should have been included, such as those illustrating the Chordata, and some of the photographs, that of T. H. Huxley being almost unrecognizable.

E. HINDLE

\section{STATISTICAL QUALITY CONTROL}

\section{Statistical Quality Control}

By Prof. Eugene L. Grant. (McGraw-Hill Industrial Organisation and Management Series.) Pp. xii +563 . (New York and London: McGraw-Hill Book Co., Inc., 1946.) $25 s$.

$\mathrm{B}$ EFORE the War, quality control methods of the statistical type were to be found in comparatively few industries. The War itself saw them introduced, frequently under Government auspices, into a wide range of industries which had previously never used them ; and in consequence there was a sudden load on the available training centres, particularly in the United States, which had any acquaintance with this kind of work. Stanford University bore a full share in the training schemes which were drawn up, and Prof. Grant, who had been lecturing there on the applications of statistical methods to engineering for some seventeen years, found his field of engagements greatly enlarged. His experience as a teacher has now assumed concrete form in this book, which exhibits throughout a most admirable appreciation of the practical aspects of the subject.

The book falls into five parts. The first is introductory and gives the beginner a very clear idea of what statistical quality control can do. Part 2 deals with the control chart for variables based on sample means and ranges; and Part 3 deals similarly with charts for the control of fraction defective. Part 4 discusses the control of quality assurance and acceptance procedures based on single and double sampling techniques.

Thus far the author is on fairly familiar ground, though the abundance of his illustrations and the careful development of the basic ideas will make these sections well worth reading even for the expert. Prof. Grant then turns, in Part 5, to the practical problems of making quality control work, and has some most interesting comments on the cost and organisational factors involved in introducing statistical methods into a factory. The resistance to quality control from the managerial and technical side in some industries has, in fact, to be experienced to be believed. Nearly all the controller's activities "cross the lines of departmental authority", and it is far from easy to persuade the head of one department to increase his expenditure in order to make a larger reduction in costs in other departments. The success ful director of a system of quality control has to be not merely a statistician and an engineer, but also a salesman, a psychologist and a diplomat.

The problem of teaching the engineer to think 'probabilistically' is in many ways an easy one. He need not worry about refinements in the theory of inference or torment himself with the question whether probability is a limiting frequency or an undefinable idea. His samples are as large as he likes to make them; probability for him is very much the same thing as relative frequency; and in the course of a very short time he accumulates so much data that he can convince himself that the ordinary laws of probability work in practice whatever their theoretical basis may be. For this reason the engineering world, from Shewhart onwards, has developed a sort of pragmatic frequency theory of probability. It may be difficult to justify logically, but it works. Prof. Grant accordingly introduces probability as a frequency concept, and it is enough for his purposes to take the direct theory as far as the derivation of the binomial and Poisson distributions. He does not require inverse probability at all, although, as he points out, some writers on quality control make an explicit use of Bayes' postulate.

There is a gratuitous footnote on page 112 which would be better omitted. "There seem to be," says the author, "two reasons why the standard error is so frequently misused in applications outside the field of quality control in manufacturing. One reason is that Shewhart's contributions to statistical theory, originally applied in manufacturing, are not so well known as they ought to be to statisticians in other fields. . . The other reason is that statisticians in other fields are not subject to the immediate check on the accuracy of their predictions which is so common in manufacturing." One can share Prof. Grant's admiration of Dr. Shewhart, one of the pioneers in introducing quality control into industry ; but I do not think Dr. Shewhart would claim to have made any contributions to statistical theory or to have taught statisticians anything they did not know about the use of standard errors. Prof. Grant invites the comment that the engineer should stick to his lathe.

But this is the only passage in the whole book to which I would take exception. The work is fluently written and well produced, and may confidently be commended to engineers and statisticians as an excellent account of the subject.

Maurice Kendall 